SŁAWOMIR ŚWIERCZYŃSKI

Polish Naval Academy, Gdynia, Poland

PIOTR ZWOLAN

Polish Naval Academy, Gdynia, Poland

\title{
HARBOUR INFRASTRUCTURE INVENTORY DEVELOPMENT WITH 3D LASER SCANNING METHOD
}

\begin{abstract}
In the Polish law harbour infrastructure is one of key elements to determine the various cargo types, available means of transport and, ultimately, the significance of any sea port. The structures, devices and installations situated within a port's boundaries, dedicated to the swift operation of the port, are all designed for tasks that involve the best use of this infrastructure.

The proper development and modernization of this infrastructure may well result in improved cooperation with road networks and transportation on land. Owing to modern technology, it is possible to scan the surrounding buildings or location with great accuracy and render three-dimensional models of the scanned objects.

These models can be used to generate harbour maps with a detailed 3D picture of the entire port and navigational infrastructure. The authors of this article present the possible applications of modern laser scanning technology in port infrastructure surveying, and in particular in the survey of a complicated wharf line on the Motława River along Długie Pobrzeże Street in Gdańsk.
\end{abstract}

\section{Keywords:}

3D laser scanning, harbour infrastructure.

\section{INTRODUCTION}

A laser scan measures the distance from a scanned object by recording the time it takes for a laser pulse to travel from the scanner to the object scanned 
and back to the detector's lenses. Additionally, the scanner registers the angle of the laser light, which allows it to determine the XYZ spatial coordinates of the measured points (called a 'point cloud') in the scanner's local system. In addition to the registering of the reflected signal — the so-called 'first echo' (FE) or the 'last echo' (LE) - modern scanners also record the intensity of the reflected signal [4].

To differentiate between the different technologies used, laser scanning can be divided into:

- ALS: Airborne Laser Scanning;

- SLS: Satellite Laser Scanning;

- TLS: Terrestrial Laser Scanning.

Various factors dictate the accuracy of the distance measured and the intensity of the laser beam reflected in the laser scanning technology: the distance from the scanned object, its features, including the material it is made from; the surface type, shape, and angle at which the object is scanned. Terrestrial Laser Scanning enables collecting a large number of very precise spatial measurements. A laser scanner can capture high density data and thus provides a high level of accuracy of the scanned objects. Its parameters include [4]:

- the given method of the distance measurement;

- the accuracy of a single measurement;

- the modelled surface precision;

- the field of vision;

- the scanning optics;

- the laser tilt method;

- the scanning speed;

- the maximum instantaneous range;

- the scan rate;

- the scan resolution;

- the integrated digital camera with zoom video;

- the data storage and transfer;

- the laser type.

Every project which requires large amounts of measurement and generates a large amount of data needs an adequate tool. In the case of laser scanning and the collection of a huge quantity of point clouds, the tool needed is a scanner. An 
increasing number of fields are making use of 3D scanning: land surveying (topography measurements), crime detection, structure inspection in civil engineering, architecture, three-dimensional city modelling, and many more.

The three-dimensional model as a product of laser scanning arises as a result of the following stages:

- scanning;

- data (point cloud) processing;

- modelling, i.e. using a specialist CAD program to create a three-dimensional model of the object scanned.

Before the first step can be taken, an appropriate scanner for the data capture should be selected. For the purposes of the surveying campaign described in the following parts of this paper, a phase-based scanner by Leica Geosystem was chosen. The ScanStation C10 model features long range and high-accuracy scanning. It is fitted with a tilt sensor, a control panel, a hard drive, an auto-adjusting video camera and a laser plummet. Thanks to the Smart X-Mirror ${ }^{\mathrm{TM}}$ design, which allows users to conduct full-dome scans very quickly using a spinning mirror, or conduct small area scans, the device is fitted with major productivity advances. The mirror spins automatically for efficient and pin-point scans. This same Smart $\mathrm{X}$-Mirror automatically aligns the internal camera image to produce fast and accurate texture mapping of point clouds [5]. The scanner used for measurements is shown in Figure 1 below.
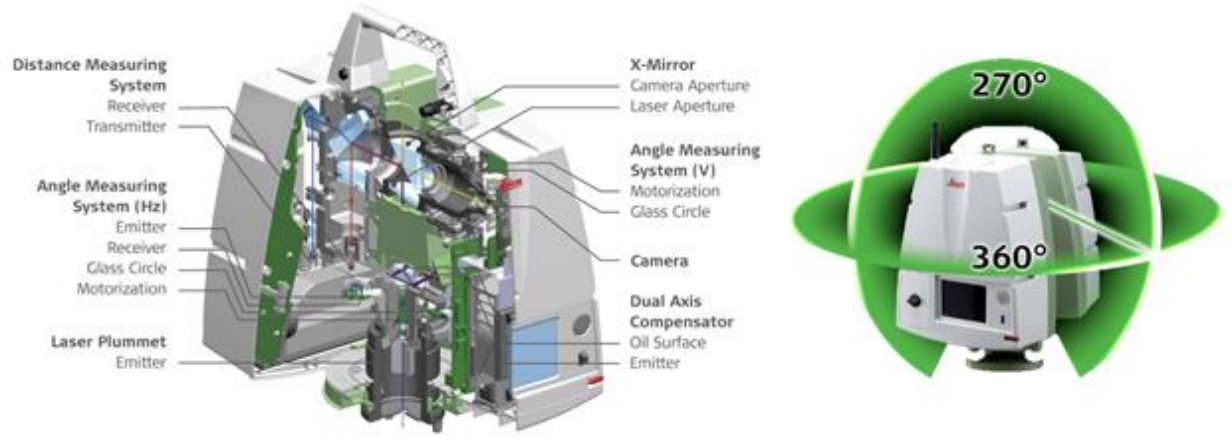

Fig. 1. Leica ScanStation C10 [source: http://myimagecollection.net]

High-Definition Surveying (HDS) systems allow for detailed topographical and civil engineering surveys. The Leica ScanStation C10 phase-based scanner 
supported by the Leica Cyclone and Leica CloudWorx software comprise a set of engineering tools integrated with CAD systems that can be used for the measurement and management of large data files and creation of accurate deliverables [5]. The tools used for scanning and data processing may reduce costs or eliminate the need for additional field verification whilst also ensuring more accurate and complete infrastructural surveys. Additional HDS systems may speed up the whole process, shorten a project's lead-time and boost project quality. The point clouds captured by the laser scanner may be used in multiple ways by different users for better data management and processing [5]. Point cloud data is processed with specialized and dedicated software that is often supplied by the scanner's manufacturer. An example of this is Leica Cyclone - a software module for managing 3D point clouds. Leica Geosystems HDS Cyclone means that point cloud users can access a set of work process options for 3D laser scanning projects in engineering, surveying, construction and other related applications. Cyclone enables the use of traverse, back-sight, and resection capabilities of the laser scanner and the creation of as-built models [5]. Cyclone is a great tool for managing large point clouds and advanced model visualizations. While processing data, users can navigate through the point clouds, move to the side, pan, zoom or rotate the view, 'see' through walls, overlap, apply shaded rendering, enhance edge display and more. Cyclone software makes it possible to import the point cloud from the scanner and export the data to the most popular format.

\section{SURVEYING CAMPAIGN}

In order to fully verify the scanner's efficiency, a scanning site in a densely-developed part of the city with many structures and a complicated wharf line had to be chosen. The authors chose the wharf of the Motława River next to the Zielona Brama (Green Gate) along Długie Pobrzeże Street, as is shown below.

The aim of the measurements was to showcase the capacities of this cutting-edge 3D laser scanning technology in harbour infrastructure surveying. The surveying campaign included the scanning of harbour structures from five scanning positions. The idea of the measurements was not to provide a visualization of the entirety of the Motława wharf infrastructure, but rather a selected part of it. The scanner's chosen positions allowed for the cleanest alignment of the resulting scanned image's individual parts. At each of the sites, the device conducted full-dome scans 
to capture the infrastructure situated on the river bank. The figure below shows the scanner sites.

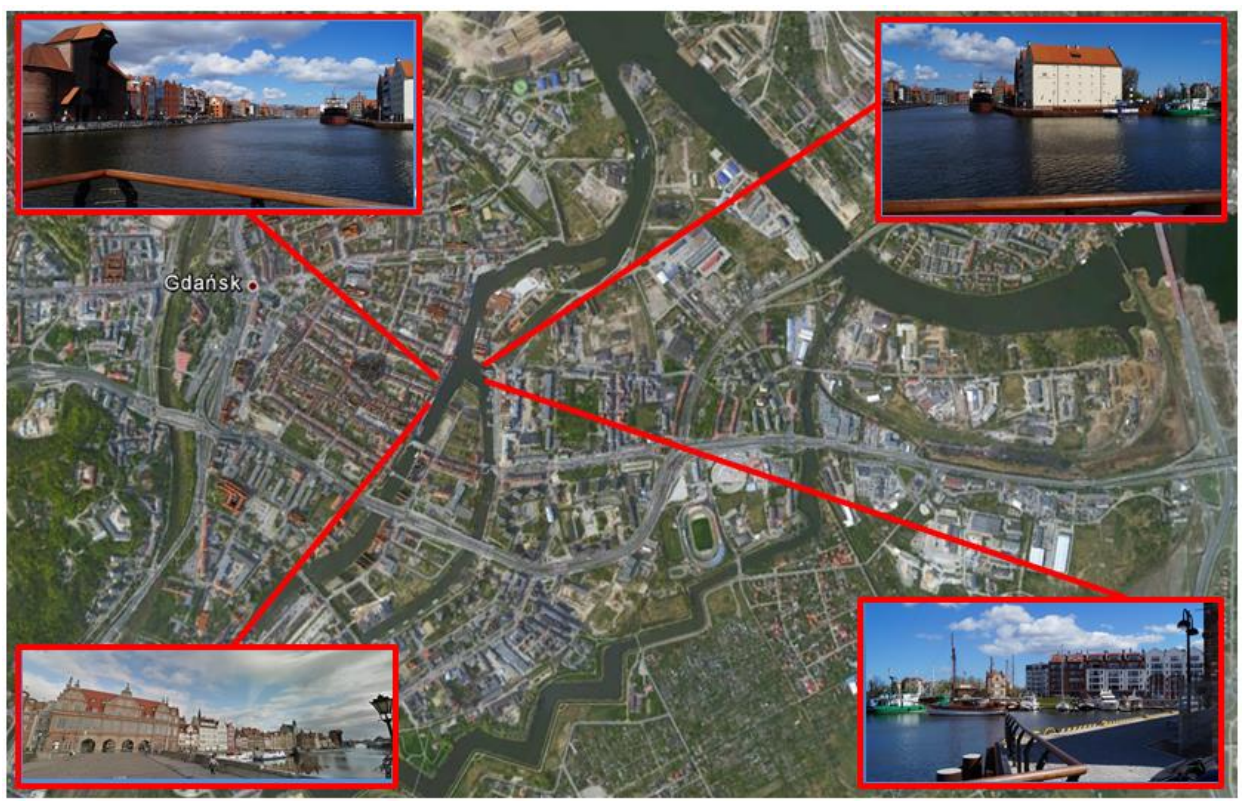

Fig. 2. The venue of the surveying campaign [source: https://www.google.pl/maps]

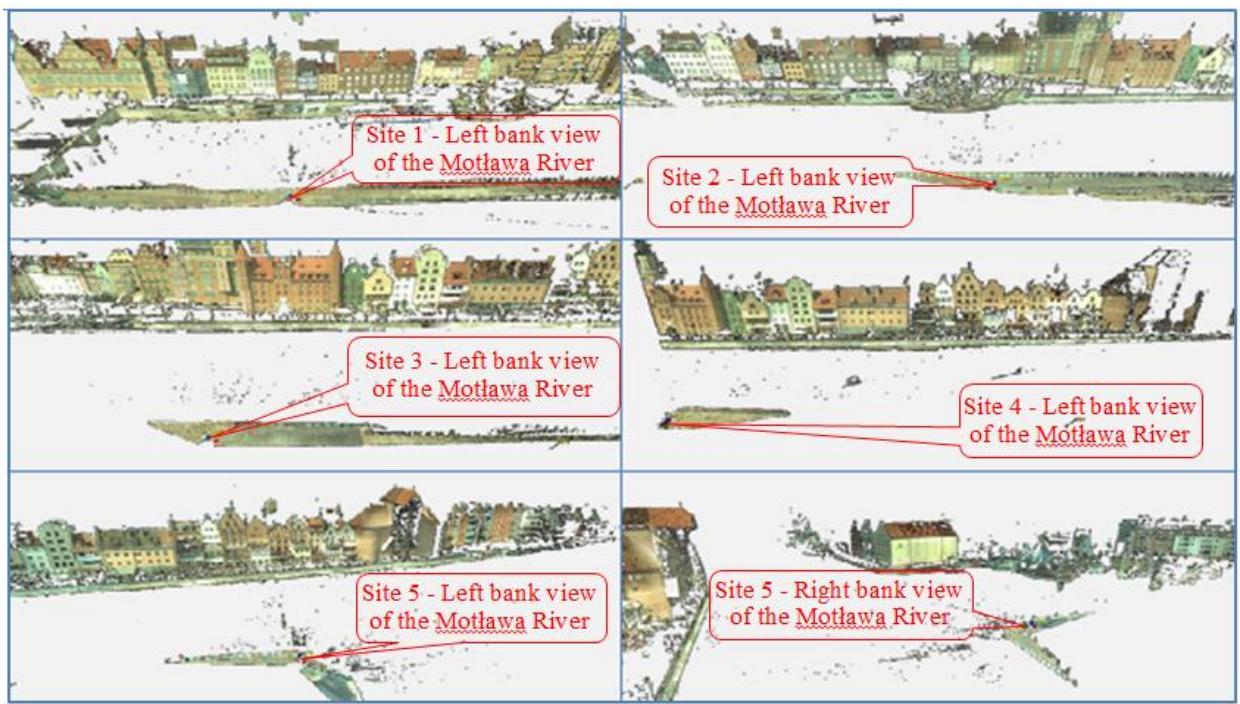

Fig. 3. Scanner sites and fragments of the scanned areas [source: https://www.google.pl/maps] 
Each scan produced a point cloud database. The data was then imported into the Leica Cyclone software, which in turn enabled the creation of a fragment of a 'larger' area of the infrastructure found on the banks of the Motława River. The size of this area depends on the device used and the number of the scanning sites and in the case described here, the area was approximately 200 metres in length. The image that was created upon the alignment of all surveys is shown in the figure below.

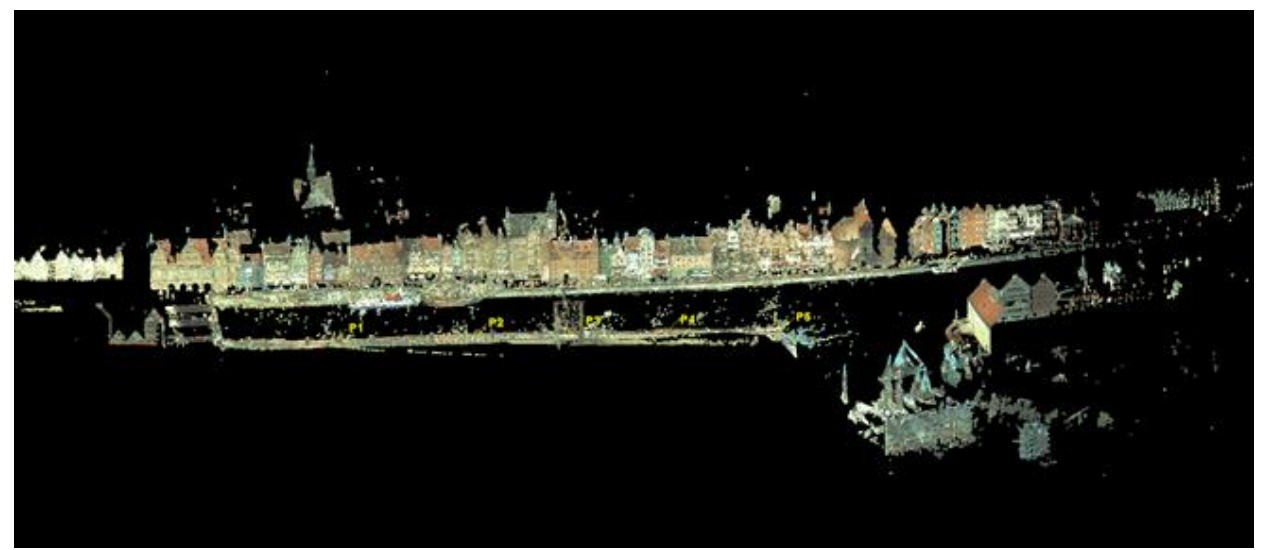

Fig. 4. Resulting image of all surveys, post alignment, of the Motława River wharf

The point cloud was obtained from the Leica ScanStation C10 phase-based scanner. The scanner measures distance by emitting rapid pulses of green laser light at a wavelength of $532 \mathrm{~nm}$. The scanning range is $300 \mathrm{~m}$ at $90 \%$ albedo; and $134 \mathrm{~m}$ at $18 \%$ albedo (where the minimum range is $0.1 \mathrm{~m}$ ). It can produce up to 50,000 points/sec. The data is recorded while the scanner rotates around a horizontal axis and the mirror reflecting the laser light — around a vertical one. The scanner enables millions of points to be captured and later defined by coordinates on three axes: X, Y, Z. This data is then displayed in the form of a three-dimensional point cloud by scanner-dedicated software. The accuracy of the survey at a $50 \mathrm{~m}$ range is: for position $-6 \mathrm{~mm}$, for distance $-4 \mathrm{~mm}$; and for horizontal and vertical angle - $60 \mu \mathrm{rad}$. The size of laser spot from 0 to $50 \mathrm{~m}, 4.5 \mathrm{~mm}$. The scanner's field of view in the horizontal plane is $360^{\circ}$ (maximum), and in vertical plane $-270^{\circ}$ (maximum). The scanning time depends on the selected resolution: that is the chosen scanning density. In this case the scanning process at a single site took about 20 minutes. The point clouds captured by the scanner during consecutive surveys are saved in separate files on the scanner's hard 
drive. Once all of the data corresponding to all points has been registered, data processing can begin. The LeicaCyclone software imports the data from the scanner to the computer. In order to obtain the point cloud covering the whole surveying campaign, all scans from all surveys need to be aligned and integrated. In order to accurately align point clouds, certain reference points, targets, are used. The identification of these tie-points during individual scans was achieved by pointing at their approximate position and, as a result, the software was able to indicate its position accurately. As reference elements, planar targets, supplied with the scanner, were used to ensure the best alignment possible.

Below are two figures which show the real image of the buildings by the Mottawa and the point cloud of the same site captured by the scanner.

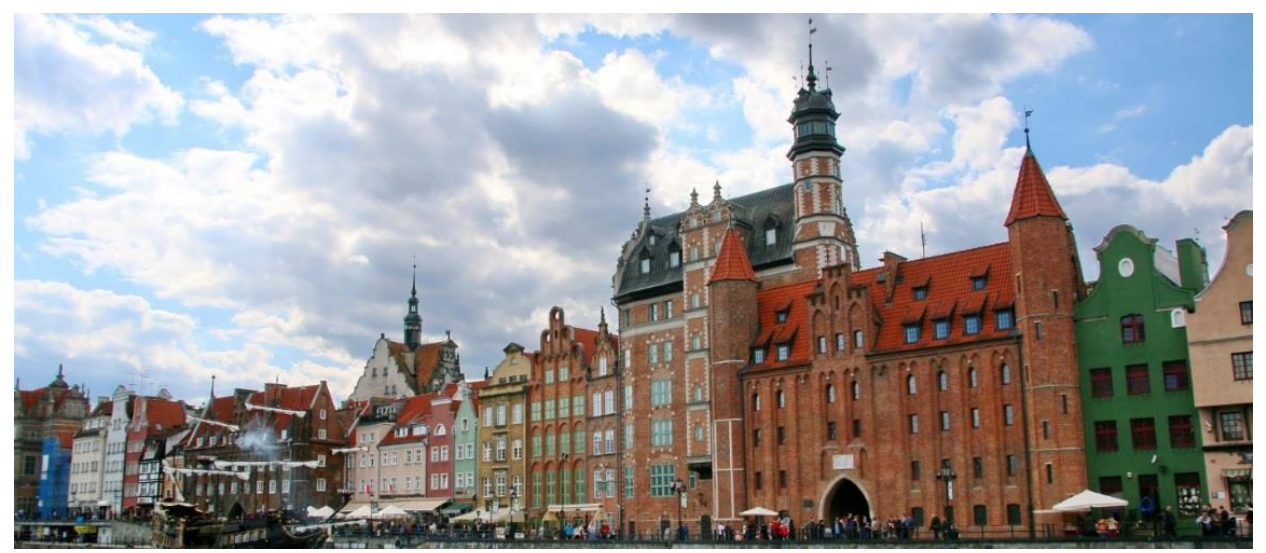

Fig. 5. Photo of buildings by the Motława River [source: https://www.google.pl/maps]

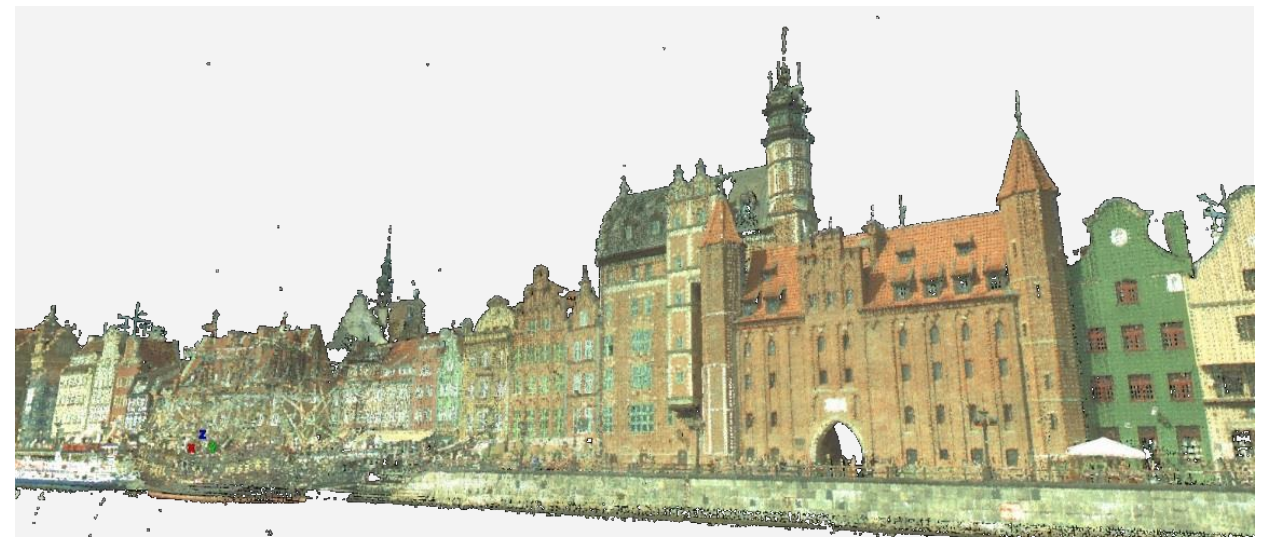

Fig. 6. A point cloud representing buildings by the Motława River 
The software supplied by the laser scanner manufacturer automatically identifies reference points and merges point clouds into one whole. After all the surveys have been integrated, the data is linked to GPS coordinates to allow the users to work on the data in CAD programs. Finally, the point cloud is 'cleaned' of all the unwanted data. Apart from buildings and other structures, a phase-based scanner captures the entire surrounding area. The point cloud contains a lot of 'noise' in its database. Once the data has been filtered, 3D models of the scanned objects are generated - the infrastructure along the Motława River in this case.

3D infrastructure models can be created from the merged point clouds or the separate surveys. The authors created the presented 3D models from the point cloud and then imported them to the Full Mission Ship Simulator, thus creating a virtual model of the basin of the Motława River, which can be loaded as one of the available simulator scenarios.

\section{CONCLUSIONS}

Harbour infrastructure is crucial to the swift operation of a port. The development and modernisation of infrastructure can improve the safety of navigation and in many cases contribute to raising the harbour's significance, as is the case with the Deepwater Container Terminal Gdańsk. From an economic standpoint, the construction and development of the container terminal is of significant importance; it is to be one of the largest container terminals in Northern Europe. As with any port, efficient operation requires periodic verification of its economic utility by means of creating an inventory of building structures. One of the ways to do so is using modern surveying techniques such as 3D laser scanning technology. Nowadays, and in various fields, 3D laser scanning is an increasingly popular tool for three-dimensional modelling by point clouds. One of such fields is building inventorisation.

Inventorisation can be performed with phase-based scanners. These are high-resolution scanners that scan physical components in their field of vision in minutes without any stoppage of works that might be being performed at a given site. The scanner captures information on the size, shape and arrangement of the objects in space. All captured points are collated in a point cloud and are assigned XYZ coordinates. The survey was performed with a Leica ScanStation C10 scanner rented from Leica Geosystems Ltd. The data relating to the scanned 
objects can be imported into dedicated data processing software. There are many such programs available on the market, but for the purposes of this article Leica Cyclone software was used. Leica Cyclone allows for comprehensive processing of point clouds which represent the scanned objects.

The obtained three-dimensional point clouds can be texture mapped and processed into $3 \mathrm{D}$ models. In the next paper, the authors show how the point clouds can be transformed into three-dimensional models and implemented to a Model Wizard - a program enabling the creation of sea basins and port infrastructure models.

\section{REFERENCES}

[1] Law about ports and sea-harbours [The Act of 20 December 1996: 'Dziennik Ustaw', 1997, No. 9, 44].

[2] Kurczyński Z., Air and satellite imaging of the Earth [in Polish], Printing House of Warsaw University of Technology, Warszawa 2006.

[3] Wolski B., Metrological monitoring of the geotechnical objects [in Polish], Krakow Technical University, Kraków 2006.

[4] http://www.skanowanie-laserowe.pl [access: 20.09.2015].

[5] http://www.leica-geosystems.pl [access: 20.09.2015].

Received September 2015

Reviewed December 2015

\section{SŁAWOMIR ŚWIERCZYŃSKI}

Polish Naval Academy

s.swierczynski@amw.gdynia.pl

PIOTR ZWOLAN

Polish Naval Academy

p.zwolan@amw.gdynia.pl

\section{STRESZCZENIE}

Infrastruktura portowa jest ważnym elementem w funkcjonowaniu portu. Co pewien czas należy dokonywać jej inwentaryzacji, aby określić stopień przydatności obiektów do dalszego funkcjonowania. 
W artykule autorzy przedstawili, jak do tego celu można wykorzystać nowoczesne metody skaningu laserowego 3D. Za pomocą skanera fazowego przeskanowano obiekty znajdujące się nad rzeką Motławą w Gdańsku. Do obróbki danych wykorzystano specjalistyczne oprogramowanie firmy Lica, która wypożyczyła skaner i oprzyrządowanie niezbędne do wykonania skaningu obiektów.

Powstała baza danych w postaci chmur punktów, które reprezentują trójwymiarową infrastrukturę nadbrzeżną. Na przygotowany zbiór punktów można nałożyć teksturę i stworzyć modele obiektów 3D, które w dalszym procesie można wykorzystać jako wizualizacje w środowisku symulatorów nawigacyjnych. 